\title{
Anggaran Pendapatan, Realisasi Belanja, dan Efektifitas Program Pendidikan Dasar Sembilan Tahun
}

\author{
Hendi Prihanto ${ }^{1}$, Suyanto ${ }^{2}$ \\ ${ }^{1}$ Universitas Pancasila, Jl. Srengseng Sawah, Jagakarsa, Jakarta Selatan 12640 \\ ${ }^{2}$ Sekolah Tinggi Ilmu Ekonomi IPWIJA, Jl. Letda Natsir No.7 Nagrak, Gn. Putri Cibubur - Bogor
}

I N F O A R T I K E L

\section{JEL Classification:}

M48

A20

Keywords:

budget revenue,

actual expenditure

and program's effectiveness.

\section{A B S TRACT}

PP 28 of 1990 regulates the implementation of nine-year compulsory education in Indonesia. Effective implementation of the program is important to be studied. This study aims to investigate the effect of budget revenues and expenditures of the effectiveness of the nine-year basic education program in Indonesia. The results of this study prove that the budget revenues and expenditures significant effect on the effectiveness of the program. This study shows that the budget allocation and absorption in the budget expenditures will determine the effectiveness of the program in Indonesia

\begin{abstract}
A B S T R A K
PP No. 28 Tahun 1990 mengatur tentang pelaksanaan wajib belajar Sembilan tahun di Indonesia. Efektifitas implementasi program tersebut penting untuk dikaji. Penelitian ini bertujuan untuk membuktikan pengaruh anggaran pendapatan dan realisasi belanja terhadap efektifitas program pendidikan dasar sembilan tahun di Indonesia. Hasil penelitian ini membuktikan bahwa anggaran pendapatan dan realisasi belanja berpengaruh signifikan terhadap efektifitas program. Penelitian inimenunjukkan bahwa pengalokasian anggaran dan penyerapan terhadap anggaran dalam realisasi belanja sangat menentukan efektifitas program di wilayah Indonesia.
\end{abstract}

\section{Pendahuluan}

Pendidikan merupakan serangkaian kegiatan yang dapat didefinisikan sebagai usaha secara sadar, terarah, dan terencana untuk mewujudkan suasana belajar dan proses pembelajaran agar peserta didik secara aktif mengembangkan potensi dirinya, kecerdasan, ahlak mulia, serta keterampilan yang diperlukan dirinya dan masyarakat. Oleh karenanya pendidikan menjadi sangat berarti dan memegang peran penting dalam pencapaian visi dan misi bangsa Indonesia.

Upaya pemerintah dalam meningkatkan pembangunan dibidang pendidikan adalah dengan mencanangkan program wajib belajar

*Email Korespondensi: ${ }^{1} h p \_t o r a n a @ y a h o o . c o m,{ }^{2}$ suyanto@cbn.net.id 
enam tahun pada PELITA III, yang kemudian secara berkesinambungan dilanjutkan dengan program wajib belajar sembilan tahun yang pelaksanaannya diatur melalui PP No. 28 Tahun 1990. Program tersebut dikatakan sudah berjalan efektif apabila memenuhi persyaratan atau sasaran program yang ditetapkan dalam tujuannya, yaitu diharapkan rakyat Indonesia sudah terbebas dari buta huruf dan sudah tuntas menempuh jenjang pendidikan minimal sembilan tahun.

Quartiana(2003), menyimpulkan bahwa terdapat pengaruh positif antara jumlah dana pendidikan yang dikeluarkan dalam anggaran pendapatan dan belanja daerahterhadap pencapaian kinerja walaupun belum efektif. Faktor yang dapat dijadikan tolokukur berhasil atau tidaknya kinerja program pendidikan dasar sembilan tahun tersebut, dapat dilihat dari indikator pencapaian kinerja pendidikan yang dinyatakan dalam APK (Angka Partisipasi Kasar), yaitu sebagai perbandingan antara jumlah murid pada jenjang pendidikan tertentu (SD, SLTP, SLTA dan sebagainya) dengan penduduk kelompok usia sekolah yang sesuai dinyatakan dengan persen. Sementara itu, fenomena yang terjadi sesungguhnya adalah:

a. APK Nasional yang dicapai dalam kurun waktu selama tahun 2006-2010 berada pada kondisi peringkat yang rendah, mengindikasikan belum efektifnya program tersebut.

b. PP No. 28 Tahun 1990 tentang wajib belajar sembilan tahun, semenjak ditetapkannya hingga tahun 2010, belum mencapai sasaran dan tujuan yang di inginkan.

$$
\text { Toyamah dan Usman }
$$

mengemukakan bahwa konsistensi pelaksanaan anggaran yang telah direncanakan menghasilkan kinerja yang efektif, dan dibutuhkan keselarasan antara anggaran dan partisipasi masyarakat. Cahyani (2010) menyatakan bahwa pengaruh partisipasi anggaran terhadap efektifitas kinerja berpengaruh positif. Anggaran pendidikan berdasar pada kebijakan anggaran yang ditetapkan oleh pemerintah, dikelola dengan peruntukan bagi anggaran di pusat dan anggaran di daerah yang diantaranya berbentuk Dana Alokasi Umum, yaitu merupakan dana yang bersumber dari pendapatan APBN yang dialokasikan dengan tujuan pemerataan kemampuan keuangan antar daerah untuk mendanai kebutuhan daerah dalam rangka pelaksanaan desentralisasi (Mardiasmo: 2002). Peranan dana alokasi umum terletak pada kemampuannya menciptakan pemerataan berdasarkan pertimbangan atas potensi fiskal dan kebutuhan nyata dari masing-masing daerah (Undang-undang No 33 Tahun 2004)

Andriana (2011) mengemukakan anggaran pendidikan yang dikelola dan teralokasikan $100 \%$, dengan kata lain apa yang sudah dianggarkan konsisten dengan realisasi pembangunan pendidikannya yang ada, sehingga tercapai kinerja yang efektif seperti yang diharapkan, selain dari anggaran dibutuhkan pula partisipasi masyarakat yang besar dalam pembangunan sektor pendidikan, alokasi anggaran relatif kecil mempengaruhi pula kinerja pendidikan. Septiana Dwiputrianti dan Suharsini (2012) mengemukakan bahwa terdapat Pengaruh secara bersama-sama (simultan) antara tahap persiapan, ratifikasi, pelaksanaan, danpelaporandanevaluasiterhadap tingkat efektifitas pengelolaan anggaran. dan Levin dalam Widodo, 2001) menyatakan organisasi yang efekif adalah organisasi yang mengoorganisir kegiatan yang diperlukan untuk mencapai tujuan yang menekankan pada analisis biaya program dikaitkan dengan hasil yang dicapai. Oleh karena itu rumusan masalah dalam penelitian dapat dikemukakan:

1. Apakah terdapat pengaruh Anggaran Pendapatan dan Realisasi Belanja terhadap Efektifitas Program secara simultan?

2. Apakah terdapat pengaruh Anggaran Pendapatan dan Realisasi Belanja terhadap Efektifitas Program secara parsial?

Dengan perumusan masalah diatas, maka tujuan yang ingin dicapai dalam penelitian :

1. Untuk membuktikan dan menjelaskan bahwa Anggaran Pendapatan dan Realisasi 
Belanja berpengaruh terhadap Efektifitas Program secara simultan

Untuk membuktikan dan menjelaskan bahwa Anggaran Pendapatan dan Realisasi Belanja berpengaruh terhadap Efektifitas Program secara parsial.

\section{Telaah Teori dan Pengembangan Hipotesis}

\subsection{Teori Pertanggung jawaban}

Accountablitysecaraumummengandung pengertian dapat dipertanggungjawabkan, bertanggung jawab atau dapat dikenakan tanggungjawab atau bahkan tidak dapat dipertanggungjawabkan. Selanjutnya Budiardjo mengartikan bahwa accountability merupakan pertanggungjawaban dari pihak yang diberi mandat untuk memerintah, kepada mereka yang memberi mandat. Dalam hal ini, rakyatlah yang memberikan kekuasaan kepada pihak lain, dan pihak lain yang dimaksudkan tersebut adalah pemerintah.

Pemerintah bertanggung jawab kepada rakyat, ini yang dinamakan sebagai kedaulatan rakyat. Lebih lanjut accountability dapat ditafsirkan secara luas, yaitu sebagai pertanggungjawaban politik. Meskipun diakui bahwa secara asasi pertanggungjawaban dalam sistem pemerintahan hanya terdapat dalam tatanan demokratis, dalam praktek mungkin didapati pada tatanan politik kediktatoran atau otoriter. Tetapi yang tidak didapati dalam kediktatoran atau otoriter adalah kebebasan menilai pertanggungjawaban dan konsekuensi yang dapat timbul dari pertanggungjawaban tersebut. Dalam sistem kediktatoran atau otoriter tidak ada kebebasan menilai. Kalaupun ada penilaian, semata-mata untuk menilai pembenaran segala tindakan pemerintah, begitu pula halnya dengan konsekuensi penilaian, tidak dimungkinkan untuk sampai pada menyatakan tidak percaya pada pemerintah atau bersikap tidak akan memberi dukungan lebih lanjut di masa datang.

Akuntabilitas merupakan suatu kewajiban untuk memberikan laporan kepada pihak lain tentang apa yang mereka lakukan atau tidak mereka lakukan, akuntabilitas juga menyangkut pertanggungjawaban kepada semua pihak yang berkepentingan (Jones 2000). Sedangkan Hatry, 1980:164 mengemukakan Akuntabilitas (accountability) merupakan suatu istilah yang diterapkan untuk mengukur apakah dana publik telah digunakan secara tepat untuk tujuan dimana dana publik tadi ditetapkan dan digunakan secara legal. Mengacu pada tiga pilar utama yang menjadi persyaratan akuntabilitas yaitu Pertama, adanya transparansi dalam menetapkan kebijakan dan menerima masukan dan mengikut sertakan berbagai institusi. Kedua, adanya standar kinerja yang dapat diukur dalam melaksanakan tugas, fungsi dan wewenang. Ketiga, adanya partisipasi untuk saling menciptakan suasana yang kondusif dalam menciptakan pelayanan masyarakat dengan prosedur yang mudah, biaya yang murah dan pelayanan yang cepat

Dalam rangka pertanggungjawaban publik, pemerintah pusat dan daerah sudah seharusnya melakukan optimalisasi anggaran yang dilakukan secara efisien dan efektif untuk meningkatkan kesejahteraan masyarakat. Pengalamanyangterjadipadasaatinipengelolaan keuangan negara masih memperihatinkan, anggaran khususnya pengeluaran melalui realisasi belanja belum mampu berperan sebagai insentif dalam mendorong laju pembangunan daerah. Disamping masih banyak ditemukan keluhan masyarakat yang berkaitan dengan pengalokasian anggaran yang tidak sesuai dengan kebutuhan dan skala prioritas, serta kurang mencerminkan aspek ekonomis, efisien dan efektif.

Dimensi reformasi lembaga sektor publik, seperti pemerintah daerah, departemen, dan lembaga dibawahnya dalam rangka pemberian pelayanan publik (public service) harus mengacu pada indikator ekonomis, efisien dan efektif yaitu dengan memberikan otonomi dan desentralisasi tanggungjawab dalam memberikan pelayanan kepada masyarakat kepada pemerintah daerah. Pemberian otonomi tersebut diharapkan dapat 
meningkatkan efisiensi dan akuntabilitas pemerintah, namun harus diperhatikan bahwa pelimpahan wewenang dan tanggungjawab dalam mengunakan dana tersebut, harus diikuti dengan pemberian diskresi kepada pemerintah daerah untuk mengunakan dana sesuai dengan prioritas dan aspirasi pemerintah daerah ( Mardiasmo : 2002)

Agar pengelolaan dana masyarakat yang sangat besar tersebut dilaksanakan secara transparan dengan memperhatikan VFM (value for money), maka diperlukan peraturan pelaksanaan dan pemeriksaan yang lebih konkrit dan tegas. Titik berat peraturan tersebut adalah koreksi total semua kesalahan dimasa lalu dan pelaksanaan VFM audit bertujuan untuk menjamin dikelolanya uang rakyat secara ekonomis, efisien, efektif akuntabel, dan berorintasi pada kepentingan publik.

Tuntutan dilaksanakannya akuntabilitas publik tersebut mengharuskan pemerintah daerah untuk tidak sekedar melakukan vertical reporting, yaitu pelaporan kepada pemerintah pusat, akan tetapi juga dilakukannya horizontal reporting, yaitu pelaporan kinerja pemerintah daerah kepada DPRD dan masyarakat sebagai bentuk horizontal accountability.

Pada dasarnya, akuntabilitas publik adalah pemberian informasi dan disclouure atas aktivitas dan kinerja finansial pemerintah daerah kepada pihak-pihak yang berkepentingan dengan laporan tersebut. Pemerintah baik pusat maupun daerah, harus bisa menjadi subjek pemberi informasi dalam rangka pemenuhan hak-hak publik, yaitu hak untuk diberi informasi, didengar aspirasinya, dan diberi penjelasan.

Bentuk pertanggungjawaban publik oleh pemerintah daerah dapat bermacammacam, Ellwood dalam Mardiasmo (226:2002), menggolongkan menjadi 4 macam yaitu :

1) Akuntabilitas Hukum dan Peraturan (accountability for probity and legality)

2) Akuntabilitas Proses (process accountability)

3) Akuntabilitas Program (program accountability)

4) Akuntabilitas Kebijakan (policy accountability)

\subsection{Anggaran dan Efektifitas Program}

Akuntabilitas merupakan suatu kewajiban untuk memberikan laporan kepada pihak lain tentang apa yang mereka lakukan atau tidak mereka lakukan, akuntabilitas juga menyangkut pertanggungjawaban kepada semua pihak yang berkepentingan (Jones 2000). Sedangkan Hatry, 1980:164 mengemukakan Akuntabilitas (accountability) merupakan suatu istilah yang diterapkan untuk mengukur apakah dana publik telah digunakan secara tepat untuk tujuan dimana dana publik tadi ditetapkan dan digunakan secara legal. Bentuk pertanggungjawaban publik oleh pemerintah daerah dapat bermacam-macam, Ellwood dalam Mardiasmo (226:2002), menggolongkan menjadi 4 macam yaitu : Akuntabilitas Hukum dan Peraturan, Akuntabilitas Proses, Akuntabilitas Program dan Akuntabilitas Kebijakan. Deddi Nordiawan, Iswahyudi Sondi Putra, dan Maulidah Rahmawati (2007:180), menyatakan bahwa penghasilan adalah peningkatan manfaat ekonomi selama suatu periode akuntansi dalam bentuk pemasukan atau penambahan aset atau penurunan kewajiban yang mengakibatkan kenaikan ekuitas yang tidak berasal dari kontribusi penanam modal.

Anggaran lain yang merupakan komponen penting dalam pelaksanaan kegiatan dalam akuntansi pemerintahan adalah anggaran belanja. Nordiawan, Putra dan Rahmawati (2007:187) menyatakan bahwa belanja dilingkungan akuntansi komersil dapat didefinisikan sebagai arus keluar dari aset atau segala bentuk penggunaan asset yang terjadi selama periode tertentu yang berasal dari produksi barang, penyerahan jasa, atau aktivitas lain yang terjadi dalam kegiatan operasional entitas. Sedangkan Definisi dalam ilmu akuntansi menurut Acconting Principle Board (APB) statement No 4, belanja didefinisikan sebagai jumlah yang diukur dalam uang dari kas yang dikeluarkan atau properti lain yang ditransfer, modal saham yang dikeluarkan, jasa 
yang diberikan, atau kewajiban yang terjadi dalam hubungannya dengan barang atau jasa yang telah atau akan diterimakan.

Steers (1985:2006) dalam Tangkilisan di dalam kaitannya dengan efektifitas, yang mengemukakan pengukuran efektifitas ini akan memberikan hasil yang lebih realistis dari pada model pengukuran lainnya, mengemukakan efektifitas terdiri dari lima dimensi konsep efektifitas antara lain meliputi: a). Kemampuan menyesuaikan diri atau keluwesan, b). Produktivitas c).Kepuasankerja,d).Kemampuan berlaba, dan e). Pencarian sumber daya. Biaya boleh jadi melebihi apa yang telah dianggarkan, boleh jadi dua kali lipat lebih besar atau bahkan tiga kali lebih besar daripada yang dianggarkan. Efektifitas hanya melihat suau program atau kegiatan telah mencapai tujuan yang telah ditetapkan (Mardiasmo, 2002 : 134). Berdasarkan kajian teori dan hubungan antara angaran dan efektifitas program, hipotesis penelitian disusun sebagai berikut:

H1 : Anggaran pendapatan berpengaruh terhadap efektifitas program pendidikan dasar sembilan.

$\mathrm{H} 2$ : Realisasi belanja berpengaruh terhadap efektifitas program pendidikan dasar sembilan tahun

Kerangka pikir terkait dengan hipotesis penelitian sebagimana tampak pada Gambar 1.

Gambar 1: Kerangka Pikir

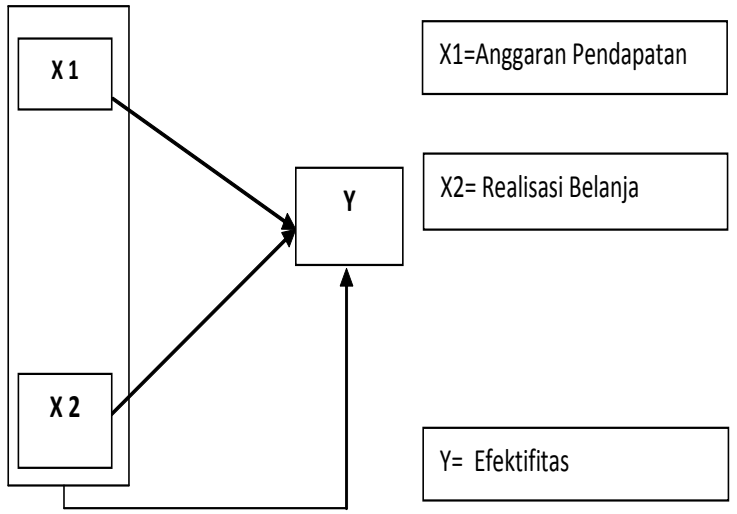

\section{Metode Penelitian}

Populasi adalah wilayah generalisasi yang terdiri objek/subjek yang memiliki kualitas dan karakteristik tertentu, sedangkan sampel merupakan bagian dari jumlah karakteristik yang dimiliki (Sugiyono: 2010). Jenis penelitian ini adalah penelitian metode kuantitatif dengan mengunakan data skunder yang terdiri dari data laporan keuangan yang penggunaannya ditujukan bagi program wajib belajar sembilan tahun. Populasi penelitian adalah Negara Kesatuan Republik Indonesia, sedangkan sampel yang akan diambil adalah provinsi yang berada di negara Indonesia yang menjadi daerah pelaksanaan program wajib belajar sembilan tahun pada kurun waktu tahun 2006-2010. Penarikan sampel pada penelitian mengunakan teknik purposive sampling, yaitu sampel yang memenuhi kriteria dalam penelitian ini adalah 33 provinsi yang diambil sebagai sampel adalah sebanyak 12 provinsi yang menjadi objek penelitian, yaitu sebagai provinsi-provinsi yang mendapat alokasi dana dekonsentrasi dari pemerintah pusat, yang merupakan pelimpahan pelaksanaan tugas pemerintah pusat di daerah dalam rangka otonomi daerah untuk kegiatan program wajib belajar sembilan tahun.

Tabel 1

Daerah Sampel Penelitian

\begin{tabular}{llllll}
\hline No & \multicolumn{1}{c}{$\begin{array}{c}\text { Nama } \\
\text { Provinsi }\end{array}$} & \multicolumn{5}{c}{ Kriteria } \\
\hline 1 & NAD & 2 & 3 & 4 \\
2 & Sumatera Utara & $\sqrt{ }$ & - & - & $\sqrt{ }$ \\
3 & Sumatera Barat & $\sqrt{ }$ & $\sqrt{ }$ & $\sqrt{ }$ & $\sqrt{ }$ \\
4 & Riau & $\sqrt{ }$ & $\sqrt{ }$ & $\sqrt{ }$ & $\sqrt{ }$ \\
5 & Kepuluan Riau & $\sqrt{ }$ & - & - & $\sqrt{ }$ \\
6 & Jambi & $\sqrt{ }$ & $\sqrt{ }$ & $\sqrt{ }$ & $\sqrt{ }$ \\
7 & Sumatera Selatan & $\sqrt{ }$ & - & - & $\sqrt{ }$ \\
8 & Bangka Belitung & $\sqrt{ }$ & $\sqrt{ }$ & $\sqrt{ }$ & $\sqrt{ }$ \\
9 & Bengkulu & $\sqrt{ }$ & $\sqrt{ }$ & - & $\sqrt{ }$ \\
10 & Lampung & $\sqrt{ }$ & - & - & $\sqrt{ }$ \\
11 & DKI Jakarta & $\sqrt{ }$ & - & - & - \\
12 & Jawa Barat & $\sqrt{ }$ & - & - & - \\
13 & Banten & $\sqrt{ }$ & - & - & - \\
14 & Jawa Tengah & $\sqrt{ }$ & - & - & - \\
15 & D. I Yogyakarta & $\sqrt{ }$ & - & - & - \\
& & & & &
\end{tabular}




\begin{tabular}{|c|c|c|c|c|c|}
\hline 16 & Jawa Timur & $\sqrt{ }$ & - & - & - \\
\hline 17 & Bali & $\sqrt{ }$ & $\sqrt{ }$ & $\sqrt{ }$ & $\sqrt{ }$ \\
\hline 18 & NTB & $\sqrt{ }$ & $\sqrt{ }$ & $\sqrt{ }$ & $\sqrt{ }$ \\
\hline 19 & NTT & $\sqrt{ }$ & $\sqrt{ }$ & - & - \\
\hline 20 & Kalimantan Barat & - & $\sqrt{ }$ & - & $\sqrt{ }$ \\
\hline 21 & Kalimantan Tengah & $\sqrt{ }$ & $\sqrt{ }$ & $\sqrt{ }$ & $\sqrt{ }$ \\
\hline 22 & Kalimantan Selatan & $\sqrt{ }$ & $\sqrt{ }$ & $\sqrt{ }$ & $\sqrt{ }$ \\
\hline 23 & Kalimantan Timur & - & $\sqrt{ }$ & - & $\sqrt{ }$ \\
\hline 24 & Sulawesi Utara & - & $\sqrt{ }$ & - & $\sqrt{ }$ \\
\hline 25 & Gorontalo & $\sqrt{ }$ & $\sqrt{ }$ & $\sqrt{ }$ & $\sqrt{ }$ \\
\hline 26 & Sulawesi Tengah & $\sqrt{ }$ & $\sqrt{ }$ & $\sqrt{ }$ & $\sqrt{ }$ \\
\hline 27 & Sulawesi Selatan & $\sqrt{ }$ & - & - & $\sqrt{ }$ \\
\hline 28 & Sulawesi Barat & - & $\sqrt{ }$ & - & $\sqrt{ }$ \\
\hline 29 & Sulawesi Tenggara & $\sqrt{ }$ & $\sqrt{ }$ & $\sqrt{ }$ & $\sqrt{ }$ \\
\hline 30 & Maluku & $\sqrt{ }$ & - & - & - \\
\hline 31 & Maluku Utara & $\sqrt{ }$ & - & - & - \\
\hline 32 & Papua & $\sqrt{ }$ & - & - & - \\
\hline 33 & Papua Barat & - & - & - & - \\
\hline
\end{tabular}

Sumber data BPS RI

Sumber : data diolah

Data yang digunakan dalam penelitian ini adalah berupa data skunder dan time series, yang dikumpulkan dari website BPS Pusat, LKPP yang dibuat dan dipublish Kementerian Keuangan dan Kementerian Pendidikan RI yang meliputi:

1. Angka Partisipasi Kasar wajib belajar sembilan tahun periode 2006-2010

2. LKPP yang diaudit oleh BPK RI pada kurun waktu 2006-2010

3. Angka penduduk yang mengikuti program yang ditetapkan. Efektifitas, secara sederhana merupakan perbandingan outcome dan output. Anggaran Pendapatan merupakan semua penerimaan rekening kas umum negara/daerah yang menambah ekuitas dana lancar dalam periode tahun anggaran yang bersangkutan yang menjadi hak pemerintah, dan tidak perlu dibayar kembali oleh pemerintah. Anggaran Belanja adalah semua pengeluaran bendahara umum negara/daerah yang mengurangi ekuitas dana lancar dalam periode tahun anggaran yang bersangkutan yang tidak akan diperoleh kembali pembayarannya oleh pemerintah.

Pengujian hipotesis dilakukan dengan uji regresi berganda yang terdiri daru Uji $\mathrm{F}$ untuk menguji layak tidaknya model yang diuji, dan Uji-t untuk menguji pengaruh masingmasing variable independen terhadap efektifitas anggaran. Uji asumsi klasik dilakukan untuk menganalisis kualitas data sekunder yang diolah. Pengujian mencakup Uji normalitas, multikolinearitas, heteroskedastisitas, dan autokorelasi. Hasil pengujian selengkapnya sebagaimana terangkum pada bagian hasil penelitian.

\section{Hasil Penelitian dan Pembahasan}

Populasi yang memenuhi kriteria dalam penelitian ini adalah sebanyak dua belas provinsi yang ada di Indonesia selama Tahun 2006-2010. Uji deskriptif data statististik bertujuan untuk mengetahui sebaran data yang ada seperti: nilai terendah, nilai tengah, nilai tertinggi dan standar deviasi pada setiap variabel yang diteliti.

Tabel 2

Deskripsi Data Penelitian

\begin{tabular}{lcccc}
\hline \multicolumn{1}{c}{ Variabel } & Minimum & Maximum & Mean & Std. Deviation \\
\hline Efektifitas program & 65.00 & 97.00 & 80.2000 & 7.28779 \\
Anggaran Pendapatan & .51 & 2.58 & 1.4655 & .68776 \\
Realisasi Belanja & 116.00 & 858.00 & 379.750 & 212.4473 \\
\hline
\end{tabular}

Sumber: Data diolah

wajib belajar sembilan tahun

Efektifitas programdidefinisikan sebagai tingkat pencapaian hasil program dengan target
Berdasarkan pada pengolahan data analisis deskriptif memiliki karakteristik sebagai berikut: $(\mathrm{N})$ menunjukan jumlah data sebesar 60, maka karakeristik masing-masing 
variabel dapat diuraikan sebagai berikut :

a. Pengaruh Anggaran Pendapatan (X1), dari 60 data nilai variabel Pengaruh Anggaran Pendapatan (X1) terkecil (minimum) adalah 0.51, sementara terbesar (maksimum) adalah 2.58. Nilai rata-rata (mean) adalah sebesar 1.465 dan standar deviasi 0.687.

b. Pengaruh Realisasi Belanja (X2), dari 60 data nilai variabel Pengaruh Realisasi Belanja (X2) terkecil (minimum) adalah 116, sementara terbesar (maksimum) adalah 858. Nilai rata-rata (mean) adalah sebesar 379.75 dan standar deviasi 212.447

c. Efektifitas Program (Y), dari 60 data nilai variabel Efektifitas (Y) terkecil (minimum) adalah 65, sementara terbesar (maksimum) adalah 97. Nilai rata-rata (mean) adalah sebesar 80.20 dan standar deviasi 7.287

Hasil uji asumsi klasik menunjukkan bahwa distribusi nilai residual model adalah normal. Hal tersebut ditunjukkan dari grafik p-plot. Uji Heteroskedastisitas bertujuan untuk menguji apakah dalam model regresi terjadi ketiaksamaan variance dari residual satu pengamatan ke pengamatan yang lain. Jika variance dari residual satu pengamatan ke pengamatan yang lain tetap, maka disebut Homoskedastisitas dan jika terjadi perbedaan disebut dengan Heteroskedastisitas hasil pengujian tidak terjadi heteroskedastisitas pada model regresi.

Salah satu caranya untuk mendeteksinya ada atau tidak multikolineritas didalam regresi adalah dengan melihat tolerance dan lawannya Variance Inflation Factor (VIF). Apabila kita hitung nilai tolerance $<0.10$ dan nilai VIF $>10$, maka telah terjadi multikolineritas yang cukup serius.

1) VIF X1 sebesar $1.109<10$ dengan nilai tolerance $0.902>0.10$ maka menunjukan tidak mengalami multikolinier.

2) VIF X2 sebesar $1.109<10$ dengan nilai tolerance $0.902>0.10$ maka menunjukan tidak mengalami multikolinier.

Apabila dilihat dari angka Durbin Watson (DW) sebesar 1.960 berada diantara du (1.730) dan 4-du (2.521) atau dengan kata lain, bahwa tidak terdapat autokorelasi positif atau negatif.

Pada penggujian hipotesis dilakukan dengan mengunakan Moderated Regresision Analysis (MRA) dimana uji interaksi merupakan aplikasi khusus regresi linear berganda dimana dalam persamaan regresinya mengandung unsur interaksi atau perkalian antara dua atau lebih variabel independen (Ghozali, 2005). Model persamaan regresi linear berganda yang digunakan dalam penelitian ini adalah sebagai berikut:

$\mathrm{Y}=\alpha \dot{\alpha}+\beta 1 \mathrm{X} 1+\beta 2 \mathrm{X} 2+\mathrm{e}$

Keterangan :

$$
\begin{aligned}
& \mathrm{Y}=\text { Efektifitas } \\
& \alpha=\text { Konstanta } \\
& \mathrm{X} 1=\text { Anggaran Pendapatan } \\
& \mathrm{X} 2=\text { Realisasi Belanja } \\
& \mathrm{e}=\text { Error }
\end{aligned}
$$

Hasil pengujian model penelitian dengna menggunakan Uji-F tampak pada Tabel berikut. Hasil pengujian menunjukkan bahwa model yang diuji, yaitu pengaruh anggaran pendapatan dan realisasi belanja berpengaruh terhadap efektifitas anggaran program pendidikan dasar sembilan tahun. Hal tersebut tampak dari nilai sig $0.000<$ nilai $\alpha=0.05$. Hasil uji koefisien determinasi dilihat dari nilai Adjusted R Square sebesar 0.669 hal ini berarti bahwa $66.9 \% \mathrm{Y}$ dapat dijelaskan oleh variasi kedua variabel independen yaitu X1 dan X2, sedangkan sisanya $(100 \%-66.9 \%=33.1 \%)$ dijelaskan oleh sebab lain diluar model atau variabel lain yang tidak diteliti. Hasil uji tersebut memperkuat pengujian model penelitian dimana model yang diuji fit dan didukung oleh kemampuan anggaran pendapatan dan realisasi anggaran dalam menjelaskan efektifitas program sebesar $66,9 \%$.

Tabel 3

Hasil Uji Statistik F ANOVA $^{b}$

\begin{tabular}{lcc}
\hline Model & F & Sig. \\
\hline Regression & 120.163 & $.000^{\mathrm{a}}$ \\
Residual & & \\
Total & & \\
\hline
\end{tabular}
a. Predictors: (Constant), X1
b. Dependent Variable: Y
Sumber : Data diolah 


\begin{tabular}{ccccc}
\multicolumn{5}{c}{$\begin{array}{c}\text { Hasil Uji Determinasi } \\
\text { Model Summary }\end{array}$} \\
\hline Model & $\mathbf{R}$ & $\begin{array}{c}\mathbf{R} \\
\text { Square }\end{array}$ & $\begin{array}{c}\text { Adjusted R } \\
\text { Square }\end{array}$ & $\begin{array}{c}\text { Std. Error } \\
\text { of the } \\
\text { Estimate }\end{array}$ \\
\hline 1 & $.821^{\mathrm{a}}$ & .674 & $\mathbf{. 6 6 9}$ & 4.19386 \\
\hline
\end{tabular}

a. Predictors: (Constant), X1

b. Dependent Variable: Y

Sumber : data diolah

Hasil Uji-t menunjukkan hipotesis pertama terbukti bahwa anggaran pendapatan berpengaruh signifikan terhadap efektifitas program. Hipotesis kedua, dan menolak hipotesis nol (Ho) artinya bahwa : Realisasi Belanja berpengaruh signifikan terhadap Efektifitas Program.

\section{Hasil Uji Statistik-t} Coefficientsa

\begin{tabular}{|c|c|c|c|}
\hline \multirow[b]{2}{*}{ Model } & \multicolumn{2}{|c|}{$\begin{array}{l}\text { Standardized } \\
\text { Coefficients }\end{array}$} & \multirow[b]{2}{*}{ Sig. } \\
\hline & Beta & $\mathbf{t}$ & \\
\hline 1 (Constant) & & 48.180 & .000 \\
\hline X1 & .858 & 10.998 & .000 \\
\hline X2 & .387 & 3.688 & .001 \\
\hline
\end{tabular}

Sumber: data diolah

Berdasarkan pada hasil pengujian hipotesis menyatakan bahwa terdapat anggaran pendapatan berpengaruh secara positif dan signifikan terhadap efektivitas program pendidikan wajib belajar sembilan tahun, dengan memiliki t hitung sebesar 10.998 lebih besar dari t tabel sebesar 1,671 dengan signifikansi 0.000 hal ini telah sesuai dan konsisten dengan hipotesis alternatif yang dikemukakan bahwa anggaran pendapatan berpengaruh terhadap efektivitas. Sehingga semakin besar anggaran pendapatan maka semakin besar pula realisasi belanja yang dikeluarkan oleh pemerintah, sehingga pembiayaan terhadap suatu program dapat berhasil dengan efektif dalam satu periode tahun anggaran. Hasil ini pun sesuai dengan yang dikemukakan Quartiana, dan Cahyani bahwa anggaran pendapatan berpengaruh terhadap pencapaian kinerja walaupun hasil yang diinginkan belum efektif.
Namun Mardiasmo mengemukakan bahwa, efektivitas dapat tercapai dengan tidak melihat berapa besar biaya yang dikeluarkan, bisa jadi biaya yang dikeluarkan lebih besar dari yang direncanakan. Dalam penelitian ini ditemukan kenyataan bahwa anggaran pendapatan yang didapatkan pada setiap tahunnya dalam pembiayaan program wajib belajar sembilan tahun, masih belum sesuai dengan yang diharapkan memenuhi kebutuhan operasional kegiatan tersebut.

Berdasarkan hasil penelitian pengujian hipotesis ini menyatakan, bahwa realisasi belanja berpengaruh positif dan signifikan terhadap efektivitas program wajib belajar sembilan tahun. Hal ini dibuktikan dengan $\mathrm{t}$ hitung 3.688 yang lebih besar dari t tabel yaitu 1.671 sehingga hipotesis diterima. Sehingga semakin tinggi belanja dan konsisten belanja yang dikeluarkan untuk pembiayaan dalam melaksanakan kegiatan program, maka semakin baik dan semakin tinggi efektivitas yang dihasilkan program tersebut. Quartiana , Andriana, Dwiputrianti dan Suharsini (2012) mengemukakan anggaran belanja berupa keakuratan, ketaatan dan kekonsistenan pengeluaranberpengaruh positifterhadapkinerja yang efektif. Johson dan Levin menyatakan organisasi yang efekif adalah organisasi yang mengoorganisir kegiatan yang diperlukan untuk mencapai tujuan yang menekankan pada analisis biaya program dikaitkan dengan hasil yang dicapai. Dalam penelitian ditemukan fenomena bahwa realisasi anggaran belanja pada setiap tahunnya yang dikeluarkan masih tidak sesuai dengan perencanaan yang telah ditentukan. Adanya realisasi yang kurang maupun melebihi perencanaan, membuktikan bahwa penyerapan anggaran pendidikan dasar tersebut tidak sesuai dengan perencanaan anggaran.

\section{Simpulan, Keterbatasan dan Implikasi Hasil Penelitian}

Penelitian ini berhasil membuktikan bahwa anggaran pendapatan berimplikasi secara positif dan signifikan terhadap efektivitas 
program dan realisasi belanja yang dikeluarkan dalam program pendidikan sembilan tahun berimplikasi secara positif dan signifikan terhadap efektivitas program. Namun beberapa hal yang menjadi permasalahan adalah bahwa secara periodik didapati adanya penyerapan anggaran yang tidak sesuai dengan perencanaan, alokasi anggaran yang tidak sesuai dengan perencanaan akan berampak negatif pada kinerja pemerintah maupun pada opini dari hasil audit yang didapat instansi yang bersangkutan. Penelitian mempunyai keterbatasan penelitian, diantaranya: peneliti hanya mengunakan dua variabel yaitu anggaran pendapatan dan anggaran belanja, rentang waktu dalam penelitian ini hanya diambil selama rentang terbatas yaitu dalam waktu lima tahun, penelitian hanya dilakukan pada 12 provinsi di Indonesia, dan Penelitian ini tidak membahas mengenai kebijakan pemerintah. Peneliti selanjutnya disarankan untuk mengunakan variabel lain yang mempengaruhi program pendidikan lebih kompleks dan bervariasi, dalam hal waktu penelitian, disarankan lebih dari lima tahun agar hasil yang didapat lebih objektif dan akurat, Sampel penelitian selanjutnya dapat lebih diperbanyak, tidak hanya mengunakan 12 provinsi di Indonesia, namun dapat lebih dari itu Penelitian akan lebih baik dan sempurna jika membahas permasalahan mengenai kebijakan yang diterapkan pemerintah dalam upaya menuntaskan program belajar sembilan tahun di Indonesia.

\section{Daftar Pustaka}

Budiarjo, Miriam. 2008. Dasar - dasar ilmu politik. Jakarta: PT. Gramedia Pustaka Utama

Deddy ordiawan, Iswahyudi Sondi Putra dan Maulidah Rahmawati. Akuntansi Pemerintahan. Cetakan Kedua. Salemba Empat. Jakarta. 2008.

Ghozali, Imam. 2005. Aplikasi Analisis Multivariate dengan program SPSS, Badan Penerbit Universitas Diponegoro, Semarang.
Granita, Quartiana. "Pengaruh anggaran pendapatan dan pelanja daerah (APBD) terhadap kinerja Dinas Pendidikan Dasar Propinsi Daerah Khusus Ibukota Jakarta: Studi kasus pelaksanaan wajib belajar pendidikan dasar sembilan tahun di Propinsi DKI Jakarta." (2003).

Mardiasmo. Otonomi dan Manajemen Keuangan Daerah. Penerbit ANDI. Yogyakarta 2002

Paslah, Asroni : Pencapaian Program Wajib Belajar 9 Tahun

Pembukaan Undang-undang Dasar Negara Republik Indonesia Tahun 1945.

Steers,M.Richard.(1985).Efektivitas Organisasi Perusahaan. Jakarta: Erlangga.

Sugiyono.(2010). MetodePenelitian Kuantitatif Kualitatif \& RND. Bandung : Alfabeta

Nurcahyani, Kunwaviyah, 2010, "Pengaruh Partisipasi Anggaran terhadap Kinerja Manajerial melalui Komitmen Organisasi dan Persepsi Inovasi sebagai Variabel Intervening”, Skripsi, Fakultas Ekonomi Universitas Diponegoro Semarang.

Peraturan Pemerintah No.28 tahun 1990 Tentang Pendidikan Dasar.

Toyamah. Nina, Usman. Syaikhu. Juni 2004. Laporan Lapangan. Alokasi Anggaran Pendidikan di Era Otonomi Daerah : Implikasinya terhadap Pengelolaan Pelayanan Pendidikan Dasar : Lembaga Penelitian SMERU

Undang-undang Dasar Negara Republik Indonesia Tahun 1945

Undang-undang No 20 Tahun 2003 Tentang

Sistem Pendidikan Nasional

Undang - undang Nomor 33 tahun 2004 tentang

Perimbangan Keuangan antara Pemerintah

Pusat dan Daerah.

Widodo, Joko. Good Governance, Telaah dari

Dimensi Akuntabilitas dan Kontrol

Birokrasi Pada Era Desentralisasi dan

Otonomi Daerah, Penerbit Insan Cendikia.

Surabaya 2001

www.bps.go.id tentang data APK (Angka Partisipasi Kasar)

www.depdiknas.go.id. tentang data pendidikan dasar 
Hendi Prihanto: Anggaran Pendapatan, Realisasi Belanja...

www.dirjen perbendaharaan.go.id tentang data keuangan

www.psp.kementerian diknas.go.id tentang data pendidikan dasar 